\title{
Suomalainen kaupunkipolitiikka uudistumispaineiden alla
}

\section{Emma Terämä}

Eero Holstila ja Timo Hämäläinen (toim.) (2019). Kaupunkipolitiikan uusi aika. Rakennustieto Oy, Helsinki. Sivumäärä: 224 . Hokkanen, Olli (2019). Suomalainen kaupunkipolitiikka: Sen tekijät ja tulkit. Väitöskirja. Helsingin yliopisto.

Kaupungit alustoina. Kaupungit luovat kasvun edellytykset. Kaupungit kärsivät eniten koronasta. Siinä esimerkkejä kaupunkipolitiikkaan vaikuttavista ilmiöistä.

Tätä kirjoittaessa on kaupunki toimintaympäristönä kokenut ennennäkemättömän kolauksen. Koronastakin riippumatta on kuitenkin mahdollista pohtia kaupunkipolitiikan suhdetta aikaan ja suomalaisten kaupunkien kehitykseen. Aiheesta on viime vuonna julkaistu kaksi ansiokasta teosta, Holstilan ja Hämäläisen toimittama kaupunkipolitiikan artikkelikokoelma sekä Olli Hokkasen väitöskirja suomalaisesta kaupunkipolitiikasta, sen tekijöistä ja tulkeista.

Kaupunkien roolin vahvistuminen on ilmeistä niin Suomessa kuin globaalissa mittakaavassa, kun katsoo esimerkiksi väestönkehitystä. Toisaalta roolin vankistuminen riippuu myös paikallisen hallinnon suhteesta valtiotason hallintoon. Tätä voisi myös kaupunkipolitiikaksi kutsua1. Molemmat mainitut teokset käyvät läpi Suomen kaupunkipolitiikan vaiheita vuosikymmenten ajalta, ja kirjassa Kaupunkipolitiikan uusi aika ne kytketään erityisen hyvin kaupungistumisen kehityskulkuihin. Molemmat teokset viittaavat myös kansainvälisiin esimerkkeihin ja verrokkeihin ja Hokkanen lisäksi teoksen luonteen vuoksi teorioihin ja käsitteisiin.

Kaupunkipolitiikan pitkiä linjoja kuvaillessaan Hokkanen kartoittaa vanhan kaupunkipolitiikan perintöä 1990-luvulla syntyneelle niin sanotulle uudelle kaupunkipolitiikalle, jolle on ominaista kaupunkien ja valtion välinen yhteistyö. Kaupunkipolitiikan uusi aika kirjan luvussaan Antikainen ja Holstila kuvaavat, kuinka kaupunkipolitiikan keskiössä on ollut 9o-luvulta lähtien talouden vahvistaminen, sosiaalinen koheesio ja ympäristöllisesti kestävä kehitys. Näitä teemoja on helppo edelleen pitää ajankohtaisina. Työkalut ja keinot yhteisen tekemisen toimeenpanossa sekä niiden menestys ohjaavina instrumentteina ovat kuitenkin vaihdelleet, kuten Hokkasen väitöskirjasta käy ilmi. Esimerkiksi

1 Hokkanen (2019) määrittelee näin: "Suomalainen kaupunkipolitiikka on tavoitteellista politiikkaa, jota tehdään ihmisten ja kaupunkien hyväksi. Sillä edistetään elinkeinotoimintaa ja kansainvälistymistä, lisätään elinvoimaa sekä ennakoidaan ja ohjataan kaupunkikehitystä, jonka tulisi olla kestävää. Kaupunkipolitiikalla huolehditaan palveluista, valvotaan kaupunkien etuja sekä perustellaan, miksi kaupunkien menestys ja niissä syntyvät uudet innovaatiot turvaavat koko Suomen kehityksen." 
ohjelmaperustainen kaupunkipolitiikka kukoisti 200o-luvun alussa. Sitten 2010-luvun alun ja Nokian romahdus päättivät merkittävät kokonaisuudet ja seurasi pitkäkestoinen "innovaatiokrapula" - Antikaisen ja Holstilan termiä lainatakseni. Instrumentteja järjesteltiin uudelleen ja rahoitusta ajettiin alas tutkimusta myöten. Myös 2020-luvun haasteiden edessä on vaikea nähdä, kuinka valtio voisi lisätä panostuksiaan kaupunki- ja aluepolitiikkaan muuten, kuin sopimuksellisuuden ja "alusta-ajattelun" kautta. Tässä kokonaisuudessa kaupungeilla ja niiden välisellä yhteistyöllä on aivan erityinen asema.

Tutkimustiedon merkitys nykyisessä kaupunkipolitiikassa nostaa päätään rahoitustilanteen epävakaudesta huolimatta. "Tutkijat luovat edellytykset tutkimukseen perustuvalle politiikalle", sanoo Hokkanen. Näin voi toivoa olevan myös kaupunkipolitiikassa. Kaupunkien omien tietovarantojen kehitys ja sisäinen hyödyntäminen, ja sittemmin tietojen avaus, ovat olleet positiivisia kehityssuuntia. Kaupunkipolitiikan uusi aika -teokseen sisältyvän Holstilan ja Soininvaaran artikkelin mukaan normatiivisen ja kantaaottavan akateemisen tutkimuksen on kuitenkin nähty olevan tervetullutta vain niin kauan, kuin se vastaa kulloinkin vallitsevia poliittisia päämääriä ja ideologioita.

Kaupunkipolitiikan uusi aika -teoksessa käydään mukavasti läpi kaupunkipolitiikan eri substanssialueita (luku 5), ja niistä saa kosolti ajateltavaa niin generalisti kuin "toisen alan" asiantuntija. Vielä tarkemmin näitä käsittelee Hokkanen väitöskirjassaan. Hän valottaa erityisesti eri politiikkojen ja sektoreiden ohjausnäkökulmaa, jännitteitä unohtamatta. Erityisen nautinnollista luettavaa olivat kuitenkin kokoomateoksen Timo Hämäläisen kynästä kirvonneet osat. Mainittakoon esimerkiksi kaupunkien kehitystyötä asukkaiden kanssa käsittelevä alaluku, jossa viitataan lukuisiin aihetta käsitteleviin tutkimuksiin, mukaan lukien valtioneuvoston tutkimus- ja selvitystoimintahanke Kansalaisyhteiskunnan tila ja tulevaisuus. Se on hyvä esimerkki valtionhallinnon halukkuudesta ymmärtää ja edistää positiivista osallistumisen murrosta. Tuotakoon tässä esille myös samaisen hallinnon halukkuus edistää tietoon perustuvaa kaupunkipolitiikkaa laajemmin!

Tämän hetken Hämäläinen mainitsee globalisaation, teknologisen kehityksen, ilmastonmuutoksen ja ihmisen roolin yhteiskunnan aktiivisena kehittäjänä. Kokonaisvaltaiseen murrokseen, jota tässä historian hetkessä läpikäymme, vaikuttavat megatrenditasoisten muutosvoimien lisäksi myös pandemia, siihen vastaaminen ja pitempään jatkuvan epävarmuuden kanssa elämään oppiminen. Hämäläisen sanoin, "kaupunkipolitiikan toimintaympäristö muuttuu yhä epävarmemmaksi ja tulevaisuuden ennustaminen sekä suunnitteleminen pitkäjänteisesti muuttuvat lähes mahdottomiksi”. Tämä pätee ehkä entistä paremmin nyt vuoden 2020 kesällä. Samanaikaisesti kaupungistumisen muka- 
naan tuoma toimintakentän laajeneminen haastaa meitä kaupunkipolitiikassa. Implisiittisen ${ }^{2}$ ja eksplisiittisen ${ }^{3}$ kaupunkipolitiikan rinnalle Hämäläinen ehdottaakin muutospolitiikkaa. Ei pöllömpi ajatus, joskin vaatii koneistolta aiempaa vahvempaa ennakointivalmiutta ja -halua.

Mitä kaupunki-valtio -yhteistyön kaupunkipolitiikassa sitten pitäisi olla? Hokkanen kuvaa väitöskirjassaan näiden kaupunkipolitiikan tekijöiden muuttumista yritysystävällisemmiksi ja strategioissaan yritysten kaltaisiksi, ehkä tämän myötä jopa toisiaan lähestyviksi. Kuten Holstila, Kolehmainen ja Laasonen kokoomateoksen artikkelissaan kuvaavat, on valtion silti mahdollistettava puitteet, edellytykset ja kyvykkyys, kun taas kaupungit omaavat strategisen ja aktiivisen roolin edistää kehitystään omiin vahvuuksiinsa perustuen. Tästä ei varmaan olla eri mieltä kaupunkipolitiikan sisällä. Vetovoimakysymyksissä kaupungit ovat Holstilan mukaan olleet "oman onnensa seppiä". Valtiokaan ei voi kääntää vääjäämätöntä kehityskulkua eikä muuttaa megatrendejä. Entistä enemmän huomio voisi kiinnittyä nöyryyteen uudistuvan toimintaympäristön edessä. Roolit kaupunkipolitiikassa eivät liene epäselvät, mutta niiden ilmeneminen käytännössä on ensiarvoisen tärkeää. Molemminpuolisen (e.m. roolit huomioon ottaen) ja hallinnon poikki ulottuvan luottamuksen kasvattaminen haasteisiin yhdessä vastattaessa on tarpeen.

Varmasti kaikki toivovat kaupunkipolitiikan kehittymistä tehokkaaksi politiikaksi, joka olisi, Hokkanen sanoin, "proaktiivista, stimuloivaa ja koordinoitua". Esimerkiksi entistä vahvemman itseorganisoituvan kaupungin malli (paitsi sisäisesti, myös suhteessa valtioon) vaatisi kuitenkin Hämäläisen mukaan hallinnon eri tasojen vetäytymistä taka-alalle. Tässä olisi oiva aasinsilta viime vuosien kokeilukulttuurin oppien laajempaan hyödyntämiseen. Vaatimuksena kuitenkin olisi sekasorron sietäminen ja onnistumisen indikaattoreiden päivittäminen. Voi olla, että nyt koettu pandemia heikentää kykyämme sietää entistä suurempaa sekasortoa, ja tämä nimenomainen kehityssuunta saa vielä odottaa. Se ei silti poissulje kaupunkipolitiikan uudistumisen mahdollisuuksia muilta osin. Hokkasen sanoin: "Kaupunkipolitiikan hautajaisilta vältytään, jos uutta suomalaista kaupunkipolitiikkaa ryhdyttäisiin kehittämään pitkäjänteisesti ja määrätietoisesti".

Kirjoittaja on Suomen ympäristökeskuksesta virkavapaalla oleva johtaja ja tutkija, joka valmistelee ministeriössä Suomen historian ensimmäistä kansallista kaupunkistrategiaa.

2 Sektoripolitiikka, jonka "tavoitteet eivät liity kaupunkien kehittämiseen, mutta joka vaikuttaa kaupunkien elinehtoihin" (Hokkanen, 2019).

3 Politiikka, jonka tavoitteet kaupunkikehityksen tukemiseksi on avoimesti ilmaistu ja joka luo edellytyksiä kaupunkien omaehtoiselle kehittymiselle (Hokkanen, 2019). 